\title{
Indian Elites and the EU as a Normative Power
}

\author{
Rajendra K. Jain \\ Centre for European Studies, School of International Studies, \\ Jawaharlal Nehru University \\ New Mehrauli Road, \\ New Delhi-110 067, India \\ E-mail: rkjain@mail.jnu.ac.in \\ Shreya Pandey \\ Centre for International Relations, \\ Central University of Jharkhand, \\ Ratu-Lohardaga Road, Brambe, Ranchi-835 205 \\ Jharkhand, India \\ E-mail: shreya.pandey@cuj.ac.in
}

\begin{abstract}
Drawing on thirty face-to-face interviews with Indian business, civil society, media and political elites during the period from September 2011 to April 2012, this article seeks to examine the perceptions of Indian elites of the European Union as a normative power. It discusses the evolution of the concept of normative power and the evolution of the EU's normative identity. It clearly outlines the expansion of the varied roles played by the EU in the course of assuming responsibilities in the capacity of civilian, ethical and normative power of Europe both within its borders and abroad. The article seeks to highlight the diverse external perceptions about the normative power of EU by focusing upon the elite opinion from India. The article captures the changing mood of the elites about the effectiveness of the normative power of the EU with the intensification of the eurozone crisis. It argues that the normative disconnect in worldviews, mindsets and practical agendas between India and the European Union has made it difficult to transform shared values into coordinated policies.
\end{abstract}

Keywords: European Union, India, Indian elites, normative power, perceptions 


\section{Introduction}

The European Union (EU) as a regional organization has time and again committed itself "to placing universal norms and principles at the centre of its relations with the Member States [...] and the world" (Diez, 2005, p. 618). The European Commission Communication An EU-India Strategic Partnership (June 2004) advocated the India-EU strategic partnership based on shared values, objectives, challenges and respect for each other as international global players and regional leaders (European Commission, 2004). In its Response to the Communication, India acknowledged that "a strategic partnership between India and the EU is special, because the two sides share values and not just interests" (Ministry of External Affairs, 2004, pp. 3-4). A strategic partnership, according to India's Minister of Commerce and Industry Kamal Nath (Economic Times, 2006, p. 1), assumes "a convergence of beliefs and a shared vision of the future of the world".

The growing feeling that the EU's strategic partnerships were neither strategic nor real partnerships led Herman Van Rompuy, President of the European Council, to call for an extraordinary meeting of the Council on 16 September 2010 to discuss the Union's strategic partnerships for the first time. Rompuy (2010, p. 2) acknowledged that "new players [such as BRICS, all of which are the Union's strategic partners] do not always share our interests and worldviews" and added, "[w]e have strategic partners, now we need a strategy". The European Council agreed on the need for Europe "to promote its interests and values more assertively and in a spirit of reciprocity and mutual benefit" (European Council, 2010, p. 1).

India wants to play a greater role in the making of new rules of the international economic and financial system in order to safeguard the interests of one sixth of humanity. Nevertheless, on most issues of substance, India's broad interests as an emerging power are consonant with those of the other major powers. In the military-political arena, India shares a common interest with other major powers in preventing the spread of Weapons of Mass Destruction and terrorism, in fostering maritime security, stabilization of weak states, and in coping with health hazards and pandemics. Co-operative relations between India and the European Union are likely to grow, despite differences over specific issues.

The Indian elites play a major role in the formulation of opinions on international issues, especially foreign policy. Amitabh Mattoo (2005) has defined policymaking elites as key decision-makers in the political, military, business and 
scientific fields as well as those who are likely to occupy key decision-making positions in the next five years. He has stated that India's policy-making elite has been mulling over in an extremely systematic manner on the issue of India's international relations and its place in the world. A consensus over the main foreign policy issues exists at the core of the strategic elite. This core is said to exist mainly in Delhi and is considered to consist of about a hundred members that include prominent journalists, retired civil servants, formal admirals, generals, and air marshals, academics and scientists, and a few politicians and businessmen. The new members are socialized through regular workshops and seminars. This group is the main conduit of advice on issues pertaining to foreign policy to even major political parties like the Congress and the Bharatiya Janata Party (BJP).

There is an "enormous information deficit" about the EU in India largely because of mutual indifference (Jain, 2001, p. 26). There is "a permanent lack of mutual knowledge" with Europe being still "marginal in the Indian collective memory" (Goddeeris, 2011, p. 7). In the absence of primary sources on Indian perceptions of the EU, opinion surveys and comprehensive media reviews, information on how Asian citizens and media perceive the European Union tends to be "impressionistic, haphazard, ill-informed and lacking scientific empirical evidence" (Holland et al., 2007, p. 24).

Only recently have some studies been undertaken on the EU's perceptions in India (Jain, 2005, p. 20; Jain \& Pandey, 2012, pp. 331-343; 2010, pp. 193-210; 2013). A few studies have looked at how the Indian print media portrayed individual EU Member States (Vaugier-Chatterjee, 2002; 2006, pp. 244-254). These studies comprise historical overviews (Subrahmanyam, 2005, pp. 69-100), reminiscences of former diplomats (Dixit, 2001, pp. 73-88) or assessments based on conversations and elite interviews (Lisbonne-de Vergeron, 2006; 2011). Others seek to explore how public opinion, political elites and civil society organizations have perceived the EU (but without conducting face-to-face elite interviews) (Fioramonti, 2007; Fioramonti \& Poletti, 2008; Mitra, 2006; Stumbaum, 2012). This article fills a major gap in perceptions studies about the EU in India as it provides a systematic, comprehensive, candid and detailed overview of the opinion of the policy-making elites. Such a study helps in validating arguments about the EU in India by means of the data generated as part of the study.

This article seeks to highlight the elite understanding in India about the normative power of the EU. The article begins by providing a conceptual understanding of what encompasses the normative power of the EU. It also highlights the instruments by means of which the EU seeks to bring about norm 
promotion in international politics. The paper discusses the elite perceptions and impressions about the normative power of the EU especially at a time when it was impacted by the euro crisis (September 2011-November 2012). The article seeks to highlight the change in opinions and outlook of the elite about the normative potential of the EU as a result of having been hit by the eurozone crisis. A comparison with interviews conducted slightly earlier (January 2010May 2010), when reverberations of the euro crisis were only slightly felt around the world, facilitates understanding about whether the economic impact upon the image of the EU as a normative power in global politics was minimal or decisive.

\section{Theoretical background}

The conceptualization of the EU as a normative power allows the debate to move beyond fruitless discussions about whether a separate EU foreign policy is needed or not. Hill (2003), while defining foreign policy as "the sum of official external relations conducted by an independent actor (usually a state) in international relations", went a long way to settling this debate. Pardo (2012, pp. 1-18) has stated that Hill's definition of foreign policy indicates that relations should be official, implies that they should be legally recognized, and gives freedom to an independent actor to conduct and maintain international relations.

\subsection{The conceptualisation of the normative idea}

As discussed by Manners (2002, p. 239), the concept of normative power has been around for several decades. Manners proceeded with reviewing works by Carr (1962), Duchêne (1973), and Galtung (1973). For example, Carr (1962) made the distinction between economic power, military power and power over opinion. He also pointed out that power is an indivisible whole and one aspect cannot exist for long without the other (Carr, 1962). Duchêne (1973, pp. 1-21) elaborated upon the normative power of the European Community as an idée force which should employ its foreign policy instruments in order to 'domesticate' relations between states. Ideological power, according to Galtung (1973), is the power of ideas. It is powerful because "the power-sender's ideas penetrate and shape the will of the power-recipient through the media of culture" (Galtung, 1973, p. 33). Galtung predicted that the European Community would eventually come to be known "just as Europe". The ideological power of Europe and the evolution of a particular European identity are believed to be inter-connected 
processes that form the fundamental basis of the concept of normative power (Scheipers \& Sicurelli, 2007, p. 437).

\subsection{Civilian, normative and ethical power Europe}

Smith (2000, cited in Manners, 2002, p. 239) has argued that the normative dimension is extremely important because the debate about civilian power involves "fundamental choices about the EU's international identity". Civilian power refers to "the acknowledgement of the indispensability of cooperation for achieving international objectives by making use of economic means and resorting to military power only as a 'residual instrument"' and possessing the will to "develop supranational structures to address critical issues of international management" (Maull, 1990, pp. 92-93). The genesis of the concepts of civilian and normative power Europe can be traced to specific circumstances and global contexts. The idea of civilian power was introduced by Duchêne in the 1970s with the onset of détente, whereas the concept of normative power Europe gained currency following the end of the Cold War. Duchêne (2006, p. 19) argued that Europe would play a distinct role externally if it acts as a "civilian group of countries long on economic power and relatively short on armed force". Manners (2006, p. 84) introduced the notion of normative power Europe in order to highlight the detour taking place from neo-colonial approaches of looking at the EU. He argued that the idea of "civilian" suggests a bias because the EU is then "compared to a state, rather than institutions and policies" (Manners, 2006, p. 239). Ethical power Europe is understood from the point of view of the functioning of the Union as a vehicle for the collective pursuit of shared second-order normative concerns which include eradication of the death penalty, democracy promotion, environmental protection and alleviation of poverty in the global South, especially in Africa (Hyde-Price, 2008, pp. 31-32). Ethical power Europe marks a shift away from the sole focus upon the "mechanisms of European power" towards taking into account both the "ends and means in combination" which tends to challenge the notion of civilian power (Jones, 2010, p. 1).

The concept of ethical power Europe permeates through its self-image of a cosmopolitan power which is conditioned by the global influence and moral standards of the values and principles that guide its policies. This suggests that the values and norms promoted by the EU are believed to have 'global moral validity' and the resultant security practices tend to exhibit an inclination more towards the protection of the individual rather than states (Nunes, 2011, p. 8). 


\subsection{The EU's normative identity}

The EU's normative difference can be traced from its historical context, hybrid polity and political-legal constitution. The EU was created after the Second World War in an era which reviled the nationalism that had led to death and destruction on a massive scale. The Europeans agreed to pool their sovereignty and resources to consolidate peace. This also led to a hybrid of supranational and international forms of governance which transcended Westphalian norms. Buzan and Little (2000, p. 359) describe the EU as "a new type of entity with actor quality". The formation of the EU has largely been the result of "elite driven treaty-based legal order". Constitutional norms, therefore, represent crucial factors which determine the EU's international identity (Manners, 2006, p. 240).

The normative identity of the EU has evolved through the adoption of numerous declarations, treaties, policies, criteria and conditions. There are five core norms which are most visible in EU laws and policies. These include peace, liberty, democracy, rule of law and respect for human rights and fundamental freedoms. There are also some minor norms (e.g., the notion of social solidarity, antidiscrimination, sustainable development and good governance) which are more contested. The "reinforcement and expansion" of the above-mentioned norms help the EU to gain greater recognition, acceptance and legitimacy and help it appear to be much "more than the sum of its parts" (Manners, 2006, p. 240).

\subsection{The harmful impact of soft instruments for norm promotion}

Normative power Europe is different from previous political formations and this predisposes it to act in a normative way. However, the ability to issue a threat to use military force should not be considered contrary to the conduct of a civilizing or normative power. Similarly, the employment of "soft instruments" should neither be considered "benign" nor "non-coercive" in nature. For instance, economic sanctions can adversely affect a populace and their effects are "largely indiscriminate". The economic sanctions imposed against Iraq four days after it invaded Kuwait in 1990 by the UN Security Council reportedly led to excessive child mortality (between 670,000 and 880,000). The children under the age of "five who died during the sanctions would not have perished if pre-war and pre-sanctions conditions [had] continued" (Marcus, 2010). Hence, the criteria of using non-military instruments alone should not be considered sufficient to identify "a polity as a normative power" (Sjursen, 2006, p. 239). 


\subsection{Growing unease with the civilian power concept (no use of military power)}

The EU came to be regarded as a civilian power long before it became known as a normative power. Duchêne (1973) predicted that Europe could become a different kind of power by relying on civilian rather than military means. The Union, he felt, would "demonstrate the influence which can be wielded by a large political cooperative formed to exert essentially civilian forms of power" since Europe did not wish to become a military superpower and compete with the Soviet Union and the United States during the Cold War apart from having extremely "amilitary values" that had devalued "purely military power" (Duchêne, 1973, p. 19). The notion of an entity being a civilian power is, in fact, a sub-set of the idea of it being a normative power. Maull (1990, pp. 92-93) argued that a civilian power sought to use economic strength in order to achieve state goals and diplomatic cooperation to solve international issues. A civilian power, he felt, also exhibited willingness to approach and accept legally binding supranational institutions in order to achieve national progress.

The Maastricht Treaty or Treaty on European Union (TEU, 1992) revived the idea of the EU being able to assume a military role by the inclusion of a defence policy in the Common and Foreign Security Policy (CFSP). For Hill (1993, p. 315), this led to a 'capability-expectations gap' consisting of three basic elements that included the ability to agree, resource availability and the instruments at Europe's disposal. Hill also argues that, while the EU possesses the necessary infrastructure in terms of capabilities and institutions, it is unable to deliver the expected foreign policy results because of the absence of decisionmaking procedures that can produce a consensus.

Civilian powers are known to pursue milieu goals rather than possession goals. Milieu goals are concerned with influencing, changing and modelling the environment in which actors operate, while possession goals are solely concerned about the final objective. Thus, civilian powers tend to focus on the common good rather than self-interest (Pardo, 2012, p. 3). They seek to foster international cooperation, solidarity and domestication of international issues rather than military solutions. Duchêne (1973, p. 19) cited Bull who, while rejecting the notion of civilian power, stressed "the need for military power". Similarly, Duchêne (1973) himself emphasized upon "civilian forms of influence and action" and extolled upon the virtues of possessing direct physical power. Manners (2002, p. 36) argued that the EU should be considered a normative power as it is known as a "promoter of norms which displace the state as the centre of concern". This notion of normative power removes the Union from the civilian-military debate and places it within the ambit of constructivism where 
the focus is on EU's international persona in the overall context of the end of Cold War and its reaction to the unilateralist assumption of the "God-given duty to spread the dream and promise of America beyond its shores" by the US which has led to "a particularly moralistic and idealistic" American foreign policy (Cox, 2003, pp. 8-9).

The "ability to shape conceptions of the normal," Manners (2002, pp. 239240) argues, refers to promotion of norms by an actor which leads it to be universally acceptable. Hence, a normative power seeks to expand and promote the principles that it considers to be universal. To that end, it seeks to adhere to the principles in practice, acting prudently and inflicting the least amount of damage or injury in the course of implementing the normative principles.

\subsection{EU's increasing willingness to use military power}

The Union's efforts to develop a 60,000-strong Rapid Reaction Force, according to some, should not be seen as a military build-up by the EU since defence and nuclear capability continued to remain under the control of the North Atlantic Treaty Organization (NATO) and this activity largely fell within the ambit of civilian tasks. This step was not welcomed by many and it was suggested that any manifestation of military power would represent a "state building project" and that the state would be recreated on a much larger scale (Smith, 2000). The implication was that this would lead to a blurring of the distinctly evolving normative image of the EU (Manners, 2002, p. 237).

The EU's external policies, according to Sjursen (2006), are not solely derived from a desire to promote its own interests, but motivated by a certain understanding of what 'ought' to be done. It is indeed inspired by a 'gradualist philosophy' seeking controlled change rather than an immediate overhaul of the existing institutions and prevalent practices in target states. Norms diffused may be considered valid and legitimate even though the Union's motives for diffusing such norms are self-regarding. A policy that focuses exclusively on the abstract validity of norms is therefore problematic (Sjursen, 2006, p. 239).

Since the inception of the ESDP and in the aftermath of the terrorist attacks in the US, Madrid, London and elsewhere, the EU has displayed an increasing willingness to flex its military muscle. This has been further enhanced by the Treaty of Lisbon, which calls for an increase in the EU's military capabilities to provide it with an operational force capable of acting beyond its borders (TEU, Art. 2, par. 1). The Treaty also urges the mobilization of military resources to prevent risks related to terrorism (TEU, Art. 2, par. 1) a very broad category 
encompassing proliferation, failed states or piracy, etc. This constitutes a reinforcement of 'normal' power Europe. The EU is therefore likely to continue to strengthen its own security by means of influencing the behaviour of others and is not likely to be averse to resorting to both military and non-military means in order to achieve this goal (Pardo, 2012, pp. 7-15).

\subsection{Current agenda for promotion of the normative image/values}

The European External Action Service (EEAS) has enumerated "diplomacy, political engagement, development assistance, civil and military crisis management in support of conflict prevention and poverty reduction, security and stability and the promotion of human rights around the world" as the foreign policy tools in order to bring "EU's foreign policy under one roof" (EEAS, 2011). This was reiterated in the General Report on the Activities of the European Union, 2011, which acknowledged that the EEAS had a great distance to travel, "both practically and politically," in order to have a collective foreign policy and bring about unison among different "people, policies and programmes" of the EU (European Commission, 2011). The main thrust of the Union's foreign policy is to "defend Europe's interests and promote its values" in order "to build and secure the peace in a number of countries in Europe, Africa and beyond, such as in Afghanistan" (EEAS, 2012). In order to ensure a stronger EU in the world, the Union has sought to pursue a more effective European

neighbourhood policy, strengthening strategic alliances, building multilateral governance and tackling global challenges, promoting peace, security and human rights around the globe, a comprehensive trade policy for Europe's growth and jobs, enlargement, investment in development and solidarity in action - in responding to humanitarian crises (European Commission, 2011).

\section{Methodology}

Pluralism was summarily rejected by elite thinkers who stated that behind the veil of liberal democracy, there lies the perpetual power of ruling elite. Classical thinkers of elitism, such as Gaetano Mosca, Vilfredo Pareto, and Robert Michels, asserted that power is always concentrated in the hands of a small elite. Modern elitists have also come to the conclusion that power always lies with a few despite strict adherence to empirical theories about the distribution of power 
(Heywood, 2008, pp. 80-81). It is necessary to understand elite perceptions of foreign policy issues since their perceptions determine their "responses to foreign policy problems” (Chaban, Elgström \& Holland, 2006, pp. 248-249).

In this study, a total of 30 elites were interviewed during the period (September 2011 to April 2012) when the EU was widely reported to be in the throes of the sovereign debt crisis. The elites were affiliated to areas of politics, media, civil society, and business. The political elites included former and present members of Parliament. In addition, the interviews included politicians belonging to the two national political parties, the Indian National Congress and the Bharatiya Janata Party, which head the two major coalitions, the United Progressive Alliance and the National Democratic Alliance, and have been alternately heading the Union government and sitting in the opposition along with leaders of various regional parties who play a key role in government formation by lending their support. The media elites interviewed included editors and leading reporters of leading national dailies (both Hindi and English), and those belonging to the electronic media. The civil society elites comprised Indians leading NGOs and INGOs, which sought to address the issues of education, discrimination, women's empowerment, hunger, poverty, rural development, and disaster management in India. The business elite included members of chambers of commerce, CEOs and top officials of companies, members of official business networks and persons associated with the formulation of Indo-EU trade and economic policies. Thus, a number of well-known personalities (five from politics, nine from media, ten from civil society, and six from business) were interviewed as part of this study. Almost all the elites had friends, family or business links in the EU. The interviewees had the most contacts in the UK, followed by France and Germany.

In the semi-structured interviews, respondents were asked a total of eighteen questions revolving around their perceptions of the EU. This article confines the analysis to only a limited number of questions, namely: When thinking about the term 'the European Union', what three thoughts come to your mind? Do you see the EU as a great power? Do you see the EU as a leader in international politics? How would you compare the importance of the EU to India in relation to other prominent regions? Looking at the future, what issues should be kept in mind when India is developing trade or government policy relating to the EU? Answers to these questions facilitated an understanding as to whether or not the Union is still regarded as a power to be reckoned with in India. It also enriched our understanding about important and sensitive issues in EU-India relations which influence Indian perceptions about the EU as a great power as well as a normative power. 
This article seeks to examine and analyze responses of Indian elites both before the eurozone sovereign debt crisis had completely set in (January 2010 to May 2010) and also during the crisis (September 2011 to April 2012). A total of 38 elites belonging to politics, business, civil society and media were interviewed during the project called "The EU through the Eyes of Asia" (see Introduction for more details). Thus, the main foci of this investigation include: First, how well is the normative image of the EU received in India? Second, whether or not the euro crisis has affected the normative power of the EU in India?

\section{Results}

The elites expressed admiration for the EU when asked as to what three spontaneous images or thoughts came to mind when they think about the EU. Examples of very positive images included: progress, the general well-being of the people, European lifestyle, culture, civilization, and amalgamation of nations, research, high-tech business, technology, development actor, humanitarian approach, post-modern political integration, collective union, trade union bloc, and inspiration for a South Asia Union, social security, human rights, richest countries, Schengen passport, the euro and market. There were several negative connotations of the EU as well (interference in India's internal affairs, identity crisis, a "Goliath" which no one has any idea about, contracting rather than expanding, complicated bureaucratic structure and problems being faced by EU nations). The responses of Indian elites tended to reflect both the core and minor norms that make up the normative identity of the EU. However, the generally positive image of the EU was tarnished by the eurozone crisis.

Indian business elites largely recognized the EU to be an international power to be reckoned with but felt that it would "take some time" for it "to come up to that position". ${ }^{1}$ The Union was described as a "very good economic power" and that the idea of the EU itself was said to be "certainly a great thought". Historically, the EU, the elites acknowledged, has been a great power as well as a military power. The EU was said to be a "historical power" whereas the United States was referred to as "the modern power". In terms of history and culture, the US "pales in significance". However, in the current international scenario where the EU is in the midst of an economic crisis, "it is the US which

$1 \quad$ JSW Steel Limited (2012). Business elite. Assistant General Manager. Interviewed in Delhi, 9 January

2 British High Commission (2012). Business elite. Welsh Affairs Officer, Business Development. Interviewed in Delhi, 15 March 
dominates". ${ }^{3}$ The Union was largely seen to be going through "troubled times". The increasing financial issues in the eurozone led to the "value [of the EU] in the global economy [...] coming down". ${ }^{4}$ The EU was not perceived to be a decisive political power because of the financial crisis and absence of a consensus on issues among Member States:

The European Union [has] [...] lot of strengths and [...] weaknesses $[\ldots]$ because they have got so many countries [...] there are differences in the implementation of a lot of policies. It is very difficult that all countries think alike [...] there are always conflicts of interest. ${ }^{5}$

Some business elites considered Europe to be "a stabilising factor" since the US economy was in decline. ${ }^{6}$ The Union, they felt, could not be considered to be a "superpower like America [...] because China is also coming up". ${ }^{7}$ Some even termed it to be "a third party in world politics". ${ }^{8}$ Unlike in the first phase of the project where the business elites were found to be most confident and optimistic about the economic power of the EU (Jain \& Pandey, 2010, p. 204), the business elites were not that confident about the EU economy in the second phase. The sovereign debt crisis had in fact led to a decline in the business elites' level of confidence in doing business with the EU as a bloc (Lisbonne-de Vergeron, 2011).

Unlike the business elites, civil society elites readily acknowledged the Union to be a formidable economic power. It was also regarded as "a political power" since France and Germany were permanent members of the United Nations Security Council. .9 Some sought to look at the EU as "a development" rather than an economic partner. China and India, they felt, were likely to occupy centre stage while the EU, which is "hanging on" to the United States, which itself was "dwindling", is unlikely to emerge as "a power-centre or source of power in the

3 Confederation of Indian Industry (2011). Business elite. Deputy Director. Interviewed in Delhi, 22 November.

4 Byucksan Private Limited (2011). Business elite. General Manager. Interviewed in Delhi, 18 September.

5 Foremost Technico Private Limited 2012). Business elite. Director (Technical). Interviewed in Delhi, 14 March.

6 Confederation of Indian Industry (2011). Business elite. Deputy Director. Interviewed in Delhi, 22 November.

7 JSW Steel Limited (2012). Business elite. Assistant General Manager. Interviewed in Delhi, 9 January.

8 Byucksan Private Limited (2011). Business elite. General Manager. Interviewed in Delhi, 18 September.

9 Save the Children (2012). Civil society elite. Programme Officer. Interviewed in Delhi, 1 December. 
future". ${ }^{10}$ The EU had "great potential", but it seemed to be suffering from a "huge identity crisis" and had become "more inward-looking"."

Thus, unlike the business elites, the civil society elites were more willing to acknowledge the EU's economic might, apparently because of their dependence on its largesse in the form of development assistance. In fact, the sovereign debt crisis was rarely mentioned by civil society elites. However, they expressed reservations about whether the EU is able to flex its political muscles in the international arena in the present circumstances. The findings of the second phase corroborate the findings of the first phase where although the EU was recognized primarily as an economic power and as a cultural power, the civil society elites felt that the EU has not emerged as a great power and was often unable to speak in one voice.

The Union, the media elites maintained, was a "power", but not a "great" power". ${ }^{12}$ The EU, according to some, could not be considered to be a "traditional power" since it did not have the military wherewithal to become a great power and because it had not been "able to get the requisite forces or platforms and deploy" them "in times of crisis". ${ }^{13}$ The limitations of the Union's diplomatic skills were witnessed during the negotiations at the Copenhagen summit. ${ }^{14}$ The EU was perceived to "some degree [to be] an economic power" since its financial stature is bolstered by Germany's robust economic performance. For some media elites, the Union was primarily regarded as an economic power, which had been adversely affected by the financial crisis and therefore needed time to recover. Some years ago, the euro was expected to gradually emerge as an alternative global currency, but it has been unable to replace the dollar. ${ }^{15}$

Some of the media elites referred to the EU as a "big power" as it had "ruled the world for 400 years", but it was not perceived as "an influential power" since it was no longer able to effectively influence developments in both Iraq and Afghanistan. ${ }^{16}$ One of the elites did acknowledge the EU's involvement in global affairs and she felt that along with the US, "different countries [Member

10 Prayas (2011). Civil society elite. General Secretary. Interviewed in Delhi, 26 November.

11 The Hunger Project (2011). Civil society elite. Programme Officer. Advocacy and Research. Interviewed in Delhi, 22 December.

12 Political Columnist (2012). Media elite. Interviewed in Delhi,16 March.

13 India Today Magazine (2012). Media elite. Senior Editor. Interviewed in Delhi, 23 January.

14 Deccan Chronicle (2011). Media elite. Editor. Interviewed in Delhi, 20 December.

15 The Telegraph (2012). Media elite.The Telegraph. Interviewed in Delhi, 28 March.

16 Deccan Chronicle (2011). Media elite. Editor. Interviewed in Delhi, 20 December. 
States] in the EU" (and not the EU as a whole) had been very proactive on global issues. ${ }^{17}$ The Union had been credited with having made major strides in the field of energy security, deep water technology, nuclear energy, green energy and "even electrical vehicles". ${ }^{18}$

The media elites felt that the EU's capabilities in agenda-setting had diminished as a result of the eurozone sovereign debt crisis. In the first phase, the media elites were generally more optimistic about the EU and its potential to emerge as a leader in international politics due to its economic might, provided it was able to address the world in one voice.

The political elites stressed the discord amongst Member States of the EU. The Union, they said, comprised "separate political entities [...] separate governments and interests". The Union's basic task was to resolve the problems amongst Member States. The EU, they felt, neither had any desire to become a superpower like America nor were Member States likely to allow this to happen were it ever to entertain such ambitions. ${ }^{19}$ The EU was said to be

[A]n artificial entity [...] [in] military, economic and other [matters] $[\ldots]$ is still country-based. There are two major nuclear powers $[\ldots]$ Britain and France [...] the economic power is Germany [...] but the EU also includes [...] some of the very poor countries of Eastern Europe or Southern Europe [...] as an entity [...] I don't think you can look at the EU as a great power. ${ }^{20}$

Unlike other elites, the political elites were more critical of the Union's predicament in the sovereign debt crisis. The EU, they said, was "in the throes of the economic crisis" and that "there is no unity anymore". Several countries in addition to Greece, Portugal, and Spain were almost on the "verge of bankruptcy". The Union's "inherent weaknesses and contradictions" led to difficulties in bailing out "Greece and some other countries". ${ }^{21}$ The economic power of the Union, they said, had "faded because you are seeing the recession in the European countries. The unemployed are marching on the streets in search of jobs". ${ }^{22}$ Thus, the

17 DFU Magazine (2012). Media elite. Editor. Interviewed in Delhi, 14 January.

18 Upstream (2012). Media elite. South Asia Correspondent. Interviewed in Delhi, 9 February.

19 Biju Janata Dal (2011). Political elite. Member of Parliament. Rajya Sabha. Interviewed in Delhi, 17 November.

20 Bharatiya Janata Party (2012). Political elite. Member of Parliament. Rajya Sabha. Interviewed in Delhi, 24 March.

21 Communist Party of India (2012). Political elite. Member of Parliament. Rajya Sabha. Interviewed in Delhi, 30 March.

22 Independent from Jharkhand (2011). Political elite. Member of Parliament. Lok Sabha. Interviewed in Delhi, 14 November. 
political elites were sceptical about the EU's role in international politics both present and future. They also seemed to be convinced that the eurozone sovereign debt crisis had tarnished the Union's image as an economic power. They were less forthcoming than others to assign an indispensable or particularly significant role to the EU in the sphere of international relations. This is a departure from the viewpoints expressed by political elites in the first phase of the project where they acknowledged that the India-EU partnership had grown significantly in recent years (Jain \& Pandey, 2010, pp. 203-204).

Indian elites were critical of the imposition of non-tariff barriers (NTBs) by the EU on grounds of violation of human rights. The EU was described as a high-cost economy and such steps were largely looked upon as protectionist and discriminatory. The imposition of an environment tax and carbon tax was a recent example. One of the elites urged that

[T] hese issues should be kept outside the realm of business [...] I am not saying that you allow use of child labour [...] but they should be separate [...] for example, there is the International Labour Organization, which is the body which should regulate such issues. They should not be brought into trade agreements and trade issues. ${ }^{23}$

NTBs tended to foster tensions in trade-related issues and create an "imbalance" between the political and trade relationship". ${ }^{24}$

Indian elites were keen that the EU should facilitate the mobility of people on both sides. The issue of migration was a sensitive one and it easily assumed political overtones in the EU. Indian elites urged Brussels to make efforts to clarify the distinction between "business movements, which are not permanent occurrences". ${ }^{25}$ This mobility was considered vital for both the service and manufacturing sectors. EU businessmen, according to one of the members of the Confederation of Indian Industries, have been "supportive" of business process outsourcing but it is the "political problems" which persist and constantly impede economic transactions. ${ }^{26}$

23 Confederation of Indian Industry (2012). Business elite. Head of Economic Research. Interviewed in Delhi, 3 April.

24 Byucksan Private Limited (2011). Business elite. General Manager. Interviewed in Delhi, 18 September.

25 Confederation of Indian Industry (2012). Business elite. Head of Economic Research. Interviewed in Delhi, 3 April.

26 Confederation of Indian Industry (2012). Business elite. Head of Economic Research. Interviewed in Delhi, 3 April. 
There was much indignation when Portugal was perceived as trying to "act as a moral force and espouse European values upon India" in the case of extradition of Abu Salem by insisting that he should not be given a death sentence. This was deemed by India to be "unnecessary interference". Such "frequent lectures on human rights and human violations" must be avoided and the EU should not try "to push these values down people's throats" ${ }^{27}$ The EU was also accused of being extremely "selective". When it came to China, many of the elites felt that EU seemed to have a different rule-book..$^{28}$

Elaborating upon the problems in the normative strategy pursued by the EU, one of the elites explained that the

$E U$ is very poor in explaining the context [...] that human rights, humanitarian intervention are by-products of that post-sovereign concept $[\ldots]$ therefore it comes out as being essentially moralistic, interfering [...] particularly, against countries like India and China which are much more similar to $19^{\text {th }}$ century European powers and much more sovereignty conscious. ${ }^{29}$

\section{Conclusions}

Shared values have not enabled India and the EU to forge a more co-operative relationship because of the normative disconnect and divergent worldviews, mindsets and practical agendas. In recent years, the content, value and scope of fundamental norms between the developed and developing countries are increasingly contested. Europe is often perceived as presenting a normative agenda in a way that seeks to undermine the competitive advantage of developing countries. To most Indians, postmodern Europe seems to be a lonely power in what is basically a Westphalian world with pre-modern and modern mindsets. India's natural reference-frame is that of hard power. To Indian elites, soft power means no power. Postmodernism is not only "alien but baffling for the Indian system" (Chaudhuri, 2011). A major impediment to India-EU relations is that "Indians don't like anyone lecturing to them. One of the great failings in the EU-India partnership has been Europe's tendency to preach to India on matters, such as human rights, that Indians believe they can handle on their own". (Tharoor, 2011)

27 Political Columnist (2012). Media elite. Interviewed in Delhi, 16 March.

28 Political Columnist (2012). Media elite. Interviewed in Delhi, 16 March.

29 Hindustan Times (2012). Media elite. Hindustan Times. Interviewed in Delhi, 27 January. 
Some 'elites' described the EU as a major player in terms of agenda-setting and regulating the norms of international behaviour. Postmodernist Europe has increasingly become a norms entrepreneur engaging in a kind of "regulatory imperialism" (Bradford, 2011, pp. 1-30) through "unilateral regulatory globalization". It seems to propagate and reflexively impose social, economic and ideological norms as global public goods that have been so successful in Europe at the global level, irrespective of other countries' stage of development, historical background, and social and cultural peculiarities. The developed countries have perceived the role of emerging powers more in terms of coopting them in a largely Western dominated system, ensuring that they played by the rules already established by the dominant players. If the global economic architecture was undergoing changes in response to the transformation of the global economy, the change was still driven by the Western, industrialized economies with little by way of agenda setting by the emerging economies. The existing architecture was sought to be retained even while accommodating new players. More tenants occupied the building, but the landlord, who set the house rules, remained the same (Saran, n.d.).

Professor Rajendra K. Jain is Chairperson and Professor of European Studies at the Centre for European Studies, School of International Studies and Jean Monnet Chair, Jawaharlal Nehru University, New Delhi. He is Adjunct Professor (Research) at the Monash European and EU Studies Centre, Monash University, Melbourne. He has been Visiting Humboldt Foundation Professor at Freiburg, Leipzig, and Tübingen universities in Germany, the Maison des Sciences de l'Homme, Paris, and the Asia-Europe Institute, University of Malaya. Professor Jain is the author/editor of a number of books and has published 95 articles/chapters in books. He is the editor of the recently published India and the European Union: Building a Strategic Partnership (2007) and of the forthcoming Multiculturalism in India and Europe (2013) and India and the European Union in a Changing World (2013).

Shreya Pandey is Assistant Professor at the Centre for International Relations, Central University of Jharkhand, Ranchi. She has been associated with several international research projects related to perception studies of the EU in India funded by the European Union and the Asia-Europe Foundation. She has attended a number of international conferences and published several articles in reputed journals and books on the EU as a global actor, EU-India relations, perception studies, nuclear proliferation and regional integration. 


\section{Interviews}

Biju Janata Dal (2011). Political elite. Member of Parliament. Rajya Sabha. Interviewed in Delhi, 17 November 2011.

Bharatiya Janata Party (2012). Political elite. Member of Parliament. Rajya Sabha. Interviewed in Delhi, 24 March 2012.

British High Commission (2012). Business elite. Welsh Affairs Officer, Business Development. Interviewed in Delhi, 15 March 2012.

Byucksan Private Limited (2011). Business elite. General Manager. Interviewed in Delhi, 18 September 2011.

Communist Party of India (2012). Political elite. Member of Parliament. Rajya Sabha. Interviewed in Delhi, 30 March 2012.

Confederation of Indian Industry (2011). Business elite. Deputy Director. Interviewed in Delhi, 22 November 2011.

Confederation of Indian Industry (2012), Business elite. Head of Economic Research. Interviewed in Delhi, 3 April 2012.

Deccan Chronicle (2011). Media elite. Editor. Interviewed in Delhi, 20 December 2011. DFU Magazine (2012). Media elite. Editor. Interviewed in Delhi, 14 January 2012.

Foremost Technico Private Limited (2012). Business elite. Director (Technical). Interviewed in Delhi, 14 March 2012.

Hindustan Times (2012). Media elite. Hindustan Times. Interviewed in Delhi, 27 January 2012.

Independent from Jharkhand (2011). Political elite. Member of Parliament. Lok Sabha. Interviewed in Delhi, 14 November 2011.

India Today Magazine (2012). Media elite. Senior Editor. Interviewed in Delhi, 23 January 2012.

JSW Steel Limited (2012). Business elite. Assistant General Manager. Interviewed in Delhi, 9 January 2012.

Political Columnist (2012). Media elite. Interviewed in Delhi, 16 March 2012.

Prayas (2011). Civil society elite. General Secretary. Interviewed in Delhi, 26 November 2011.

Save the Children (2012). Civil society elite. Programme Officer, Interviewed in Delhi, 1 December 2012.

The Hindu (2012). Media elite. Senior Assistant Editor. Interviewed in Delhi, 25 March 2012.

The Hunger Project (2011). Civil society elite. Programme Officer. Advocacy and Research. Interviewed in Delhi, 22 December 2011.

The Telegraph (2012). Media elite. The Telegraph. Interviewed in Delhi, 28 March 2012. 
Upstream (2012). Media elite. South Asia Correspondent. Interviewed in Delhi, 9 February 2012.

Videh (2012). Civil society elite. President. Interviewed in Delhi, 5 February 2012.

\section{References}

Basu, N. (2012), 'EU-India Summit to assess FTA progress,' Business Standard, 9 February 2012. Retrieved from http://business-standard.com/india/news/eu-indiasummit-to-assess-fta-progress/464162/ [accessed 24 May 2012]

Bradford, A. (2011), 'European Regulatory Imperialism.' [Draft] Retrieved from http:// esnie.org/pdf/Florence_2011/Bradford.pdf [accessed 1 Sep 2011]

Bull, H. (1982), 'Civilian Power Europe: A Contradiction in Terms?' Journal of Common Market Studies, vol. 21, no. 2, pp. 149-170.

http://dx.doi.org/10.1111/j.1468-5965.1982.tb00866.x

Buzan, B. \& Little, R. (2000), International Systems in World History: Remaking the Study of International Relations, Oxford: Oxford University Press.

Carr, E. H. (1962), The Twenty Years' Crisis 1919-1939: An Introduction to the Study of International Relations, London: Macmillan.

Chaban, N.; Elgström, O. \& Holland, M. (2006), 'The European Union as Others See It,' European Foreign Affairs Reviews, vol. 11, no. 2, pp. 245-262.

Chaudhuri, P. P. (2011), Europe and the Rise of Asia, Jean Monnet Lecture, School of International Studies, Jawaharlal Nehru University, held on 17 October 2011.

Cox, M. (2003), “The Empire's Back in Town: or America's Imperial TemptationAgain,” Millenium: Journal of International Studies, vol. 32, no. 1, pp. 1-27. http://dx.doi.org/10.1177/03058298030320010101

Diez, T. (2005), "Constructing the Self and Changing Others: Reconsidering 'Normative Power Europe'," Millennium, Journal of International Studies, vol. 33, no. 3, pp. 613-636.

Dixit, J. N. (2001), 'India and Europe: Perceptions and Misperceptions,' in R. K. Jain (ed.) India and Europe in the New Millennium, New Delhi: Radiant, pp. 73-88.

Duchêne, F. (1973), 'The European Communities and the Uncertainties of Interdependence,' in M. Kohnstamm \& W. Hager (eds.) A Nation Writ Large? Foreign Policy Problems before the European Community, London: Macmillan, pp. 1-21.

EEAS (2011), Setting up the EEAS, by David O'Sullivan, Chief Operating Officer, European External Action Service IIEA, Dublin, 14 January 2011. Retrieved from http://www.eeas.europa.eu/speeches/2011_1201_dos_iiea_en.pdf [accessed 21 Jun 2012] 
- (2012), What we do, European Union External Action Service website. Retrieved from http://eeas.europa.eu/what_we_do/index_en.htm [accessed 20 May 2012]

Economic Times (2006), 'India-USA: Equal Partners,' Economic Times Supplement, 2 March 2006.

European Commission (n.d.), An EU-India Strategic Partnership, Communication from the Commission to the Council, the European Parliament and the European Economic and Social Committee of 16 June 2004, COM(2004) 430 final, New Delhi: Delegation of the EC.

(2011), General Report on the Activities of the European Union (2011). Retrieved from http://europa.eu/generalreport/pdf/rg2011_en.pdf [accessed 20 May 2012]

European Council (2010), General Secretariat: Conclusions, 16 October 2010, EUCO 21/1/10 REV 1, 12 October 2010.

Fioramonti, L. (2007), 'Different Facets of a Strategic Partnership: How the EU is Viewed by Political and Business Elites, Civil Society and the Press in India,' European Foreign Affairs Review, vol. 12, no. 3, pp. 349-362.

Fioramonti, L. \& Poletti, A. (2008), 'Facing the Giant: Southern Perspectives on the European Union,' Third World Quarterly, vol. 29, no. 1, pp. 167-180. http://dx.doi.org/10.1080/01436590701762900

Galtung, J. (1973), The European Community: A Superpower in the Making, London: Allen and Unwin.

Goddeeris, I. (2011), EU-India Relations, Policy Brief No. 16, May 2011, Leuven Centre for Global Governance Studies, Leuven.

Heywood, A. (2008), Political Theory: An Introduction, New York: Palgrave Macmillan. Hill, C. (1993), “The Capability-Expectations Gap or Conceptualising Europe's International Role," JCMS: Journal of Common Market Studies, vol. 31, no. 3, pp. 305-328.

http://dx.doi.org/10.1111/j.1468-5965.1993.tb00466.x

_ (2003), The Changing Politics of Foreign Policy, Basingstoke: Palgrave Macmillan.

Holland, M.; Ryan, P.; Nowak, A. Z. \& Chaban, N. (2007), 'Introduction: the EU through the Eyes of Asia,' in M. Holland et al. (eds.) The EU through the Eyes of Asia: media, public and elite perceptions in China, Japan, Korea, Singapore and Thailand, Singapore: Asia Europe Foundation, pp. 23-29.

Hyde-Price, A. (2008), “A 'tragic actor'? A realist perspective on 'ethical power Europe'," International Affairs, vol. 84, no. 1, pp. 29-44.

http://dx.doi.org/10.1111/j.1468-2346.2008.00687.x

India, Ministry of External Affairs (2004), EC Communication titled "An EU-India Strategic Partnership” - India's Response, 27 August 2004, pp. 3-4.

Jain, R. K. (2001), EU-India Summit and Beyond, Paper presented at the EU-India Think Tank Seminar, Brussels, European Commission, 15-16 October 2001.

— (2005), 'How They See Us,' E! Sharp, Brussels, March-April 2005, p. 20. 
- (2010), "India's Relations with the European Union," in D. Scott (ed.) Handbook of India's International Relations, London: Routledge, pp. 223-232. http://dx.doi.org/10.1007/s10308-010-0258-7

Jain, R. K. \& Pandey, S. (2012), 'The Public Attitudes and Images of the European Union in India,' India Quarterly, vol. 68, no. 4 (December), pp. 331-343.

- (2010), 'The European Union in the Eyes of India,' Asia Europe Journal, vol. 8, no. 2, pp. 193-210.

(2013), 'Perceptions and Visibility of the European Union in India: A Study of the Media, Elites, and Public Opinion,' in J. Zajaczkowski, J. Schottli \& M. Thapa (eds.) India in World Politics and Economy, New Delhi: Routledge.

Jones, O. (2010), 'The European Union: Power and Ethical Goals,' e-International Relations, 20 December 2010. Retrieved from http:/www.e-ir.info/2010/12/20/ the-european-union-power-and-ethical-goals/ [accessed 23 Jun 2012]

Lisbonne-de Vergeron, K. (2006), Contemporary Indian Views of Europe, London: Chatham House \& Royal Institute of International Affairs, Retrieved from http://www.chathamhouse.org/publications/papers/view/108304 [accessed 30 Sep 2011]

- (2011), Chinese and Indian views of Europe since the Crisis: New Perspectives from the Emerging Asian Giants, The Robert Schuman Foundation. Retrieved from http://www.robert-schuman.eu/ouvrage.php?num=138 [accessed 23 May 2012]

Lucarelli, S. \& Fioramonti, L., eds. (2010), The External Image of the European Union: Phase Two, GARNET Working Paper Series, no. 62. Retrieved from http:// www.garnet-eu.org/index.php?id=27 [accessed 1 Dec 2010]

Manners, I. (2002), 'Normative Power Europe: A Contradiction in Terms?' JCMS: Journal of Common Market Studies, vol. 40, no. 2, pp. 235-258. http://dx.doi.org/10.1111/1468-5965.00353

- (2006), 'Normative Power Europe Reconsidered: Beyond the Crossroads,' Journal of European Public Policy, vol. 13, no. 2, pp. 182-199.

http://dx.doi.org/10.1080/13501760500451600

Marcus, J. (2010), 'Analysis: Do economic sanctions work?' BBC News Middle East, 26 July 2010. Retrieved from http://www.bbc.co.uk/news/world-middleeast-10742109 [accessed 25 Jul 2012]

Mattoo, A. (2005), "India's International Relations: The Search for Stability, Space and Strength," in A. Ayres \& P. Oldenburg (eds.) India briefing: Takeoff At Last? New York: M.E. Sharpe \& Asia Society, pp. 81-106.

Maull, H. W. (1990), 'Germany and Japan: The New Civilian Powers,' Foreign Affairs, vol. 69, no. 5, pp. 91-106. http://dx.doi.org/10.2307/20044603

Mitra, S. K. (2006), The Novelty of Europe as seen from the Periphery: Indian Perception of the 'New Europe' in a Multi-polar World, Heidelberg Papers in South Asian and Comparative Politics, Working Paper, no. 28 (April). 
Nunes, I. F. (2011), 'Civilian, Normative and Ethical Power Europe: Role Claims and EU Discourses,' European Foreign Affairs Review, vol. 16, no. 1, pp. 1-20.

Pardo, R. P. (2012), 'Normal Power Europe: Non-Proliferation and the Normalization of EU's Foreign Policy,' European Integration, vol. 34, no. 1, pp. 1-18. http://dx.doi.org/10.1080/07036337.2011.566334

Saran, S. (n.d.), 'Global Governance and Emerging Economies - An Indian Perspective.' Retrieved from www.icrier.org/pdf/Shyam\%20Saran.pdf [accessed 23 May 2012]

Scheipers, S. \& Sicurelli, D. (2007), 'Normative Power Europe: A Credible Utopia?' JCMS: Journal of Common Market Studies, vol. 45, no. 2, pp. 435-457. http://dx.doi.org/10.1111/j.1468-5965.2007.00717.x

Sjursen, H. (2006), 'The EU as a 'normative' power: how can this be?' Journal of European Public Policy, vol. 13, no. 2, pp. 235-251. http://dx.doi. org/10.1080/13501760500451667

Smith, K. E. (2000), 'The End of Civilian Power EU: A Welcome Demise or Cause for Concern?' International Spectator, vol. 35, no. 2, pp. 11-28.

Stumbaum, M.-B. U. (2012), How does Asia view the EU? Security in an Interpolar World, NFG Working Paper, no. 1(2012). Retrieved from https://asianperceptions. eu/system/files/private/NFG_Working_Paper_01_2012.pdf [accessed 23 May 2012]

Subrahmanyam, S. (2005), 'Taking stock of the Franks: South Asian views of Europeans and Europe, 1500-1800,' Indian Economic Social History Review, vol. 42, no. 1, pp. 69-100.

http://dx.doi.org/10.1177/001946460504200103

Tharoor, S. (2011), “New India, Old Europe,” Project Syndicate, 15 November 2011. Retrieved from www.project-syndicate.org/commentary/new-india--old-europe [accessed Oct 2013]

Van Rompuy, H. (2010), We have strategic partnerships, now we need a strategy, Message from Herman Van Rompuy in the run-up to the European Council, 14 September 2010. Retrieved from http://www.consilium.europa.eu/uedocs/cms Data/docs/pressdata/en/ec/116494.pdf [accessed Oct 2013]

Vaugier-Chatterjee, A. (2002), 'Remembrance of Things Postponed: The Image of France in the Indian Press since 1989,' Paper presented at the Indian Council of Social Science Research-Maison des Sciences de l'Homme seminar 'Indo-French Relations in a Changing World,' 7-8 March 2002.

(2006), 'The Image of France in the Indian Press since 1989,' in K. Voll \& D. Beierlein (eds.) Rising India - Europe's Partner? Foreign and Security Policy, Politics, Economics, Human Rights and Social Issues, Media, Civil Society and Intercultural Dimensions, New Delhi: Mosaic Books, pp. 244-254. 